New Test. Stud. (2021), 67, pp. 260-283. () The Author(s), 2021. Published by Cambridge University Press. This is an Open Access article, distributed under the terms of the Creative Commons Attribution licence (http://creativecommons.org/ licenses/by/4.o/), which permits unrestricted re-use, distribution, and reproduction in any medium, provided the original work is properly cited.

doi:10.1017/S0028688520000296

\title{
Why Did Paul Skip Alexandria? Paul's Missionary Strategy and the Rise of Christianity in Alexandria
}

\author{
BENJAMIN SCHLIESSER \\ Theologische Fakultät der Universität Bern, Institut für Neues Testament, \\ Länggassstrasse 51, CH-3012 Bern, Switzerland.Email: benjamin.schliesser@theol. \\ unibe.ch
}

Why did Paul skip Alexandria? Why is there a blank spot on his missionary map? What prompted him to make plans to travel west rather than south? The lack of scholarly interest in this question is almost as conspicuous as the lack of sources for earliest Christianity in Alexandria. This article surveys and categorises the rather random hypotheses offered in scholarship. They relate to Paul's selfunderstanding as a missionary, to his theological raison d'être, to religious and cultural aspects, and to political circumstances. The most plausible answer concerns early Christian mission strategy: Paul skipped Alexandria because it was a Jewish city and as such part of the Jewish-Christian mission.

Keywords: Alexandria, Paul, mission strategy, politics, Letter to the Romans, Roman Empire

\section{Introduction}

The rise of Christianity in Alexandria remains a puzzle. ${ }^{1}$ Adolf von Harnack's assessment from the beginning of the last century is often quoted:

1 Important studies from the past thirty years include A. M. Ritter, 'Das frühchristliche Alexandrien im Spannungsfeld zwischen Judenchristentum, "Frühkatholizismus" und Gnosis', Charisma und Caritas: Aufsätze zur Geschichte der Alten Kirche (Göttingen: Vandenhoeck \& Ruprecht, 1993) 117-36; G. Dorival, 'Les débuts du christianisme à Alexandrie', Alexandrie: une mégapole cosmopolite (ed. J. Leclant; Paris: Académie des Inscriptions et Belles-Lettres, 1999) 157-74; A. Jakab, Ecclesia Alexandrina: Evolution sociale et institutionnelle du Christianisme Alexandrin (IIe et IIIe siècles) (Christianismes anciens 1; Frankfurt: Lang, 2001); A. Martin, 'Aux origins de l'Alexandrie chrétienne: topographie, liturgie, institutions', Origeniana Octava: Origen and the Alexandrian Tradition, vol. I (ed. L. Perrone; BETL 164; Leuven: Leuven University Press, 2003) 105-20; S. C. Mimouni, 'A la recherche de la communauté chrétienne d'Alexandrie aux Ier-IIème siècles', Origeniana Octava: Origen and the Alexandrian Tradition, I.137-63; B. A. Pearson, 'Cracking a Conundrum: Christian Origins in Egypt', Studia Theologica 57 (2003) 61-75; idem, Gnosticism and Christianity in Roman and Coptic Egypt (SAC; New York: T. \& T. Clark, 
'The worst gap in our knowledge of early church history is our almost total ignorance of the history of Christianity in Alexandria and Egypt ... up till 180 AD. ${ }^{2}$ The purpose of this study is not so much to add to this convoluted problem, ${ }^{3}$ but rather to tackle it from an angle which might seem unrelated on first glance: why did Paul skip Alexandria? Why did Alexandria not appear on the Pauline missionary map? Why would he ignore the opportunity to reach out to the numerous proselytes and God-fearers who were present in large numbers in Alexandria and who elsewhere provided 'a nucleus for the churches' which Paul founded in other urban centres? ${ }^{4}$ Why did Alexandria remain out of sight after his missionary journeys, even after delivering the collection to the Jerusalem community? What prompted him to make plans to travel to the Latin-speaking Spain after conclud-


(Rom 15.23)?

The lack of scholarly interest in this question is almost as conspicuous as the lack of sources for earliest Christianity in Alexandria. Adolf Deissmann once noted that there is but one thing that strikes him as 'peculiar': that Paul 'should never have gone to Egypt, especially to Alexandria, the international head-quarters of the Jews of the Dispersion'. ${ }^{5}$ He refers to three rather minor 'Alexandrian

2004); idem, 'Egypt', The Cambridge History of Christianity, vol. I: Origins to Constantine (ed. M. M. Mitchell and F. M. Young; New York: Cambridge University Press, 2006) 331-50; A. Fürst, Christentum als Intellektuellen-Religion: Die Anfänge des Christentums in Alexandria (SBS 213; Stuttgart: Katholisches Bibelwerk, 2007); B. A. Pearson, 'Earliest Christianity in Egypt: Further Observations', The World of Early Egyptian Christianity: Language, Literature, and Social Context. Essays in honor of David W. Johnson (ed. J. E. Goehring and J. A. Timbie; CUA Studies in Early Christianity; Washington: Catholic University of America Press, 2007) 97-112; M. Lang, 'Spuren des frühen ägyptischen Christentums' (PhD diss., University of Vienna, 2008); M. Choat, 'Christianity', The Oxford Handbook of Roman Egypt (ed. C. Riggs; Oxford: Oxford University Press, 2012) 474-89; R. A. Kraft and A. Luijendijk, 'Christianity's Rise after Judaism's Demise in Early Egypt', Partings: How Judaism and Christianity Became Two (ed. H. Shanks; Washington: Biblical Archaeology Society, 2013) 179-85; M. Choat, 'Egypt's Role in the Rise of Christianity, Monasticism and Regional Schisms', A Companion to Greco-Roman and Late Antique Egypt (ed. K. Vandorpe; Hoboken: Wiley, 2019) 449-70; S. Huebner, Papyri and the Social World of the New Testament (Cambridge: Cambridge University Press 2019) 8-15. For a fuller bibliography, see B. Schliesser, 'Jewish Beginnings: Earliest Christianity in Alexandria', Alexandria: Hub of the Hellenistic World (ed. B. Schliesser, J. Rüggemeier, T. Kraus and J. Frey; WUNT; Tübingen: Mohr Siebeck, 2021) 367-97, at 367 n. 1.

2 A. von Harnack, Mission and Expansion of Christianity in the First Three Centuries (trans. and ed. J. Moffatt; 2 vols.; New York: Putnam/London: Williams and Norgate, $1908^{2}$ ) II.158.

3 On my own view, see Schliesser, 'Jewish Beginnings'.

4 F. F. Bruce, Paul: Apostle of the Free Spirit (Exeter: Paternoster, 1977) 129.

5 A. Deissmann, Paul: A Study in Social and Religious History (London: Hodder \& Stoughton, $\left.1926^{2}\right) 229$. 
accents' in Paul's (Lukan) biography: his encounter and co-operation with Apollos in Corinth (Acts 19.1; 1 Cor 3.6), the occasion when he was taken to be an 'Egyptian' (Acts 21.38) and his travels on Alexandrian ships (Acts 27.6; 28.11). ${ }^{6}$

If scholars hypothesise about the question of why Paul skipped Alexandria at all, their answers are quite diverse. They relate to Paul's self-understanding as a missionary, to his theological raison d'être, to religious and cultural aspects, and to political circumstances. In the course of the following argument, it will become apparent that answers to the title question are intricately related to the question of the rise of earliest Alexandrian Christianity.

\section{Theological and Scriptural Reasons}

\subsection{Alexandria Was Not Part of the 'Table of Nations'}

James Scott argues that the Jewish ethnographic and geographic tradition of the 'Table of Nations' of Genesis 10 (cf. 1 Chron 1.1-2.2) and its reception in Second Temple Judaism was formative for Paul's mission strategy. ${ }^{7}$ Rom 15.19 is crucial for Scott's argument: 'from Jerusalem and as far around as Illyricum

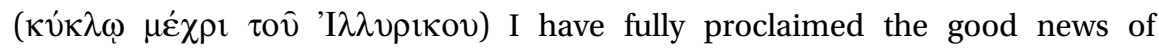
Christ.' According to Scott, Paul's mission starts in Jerusalem as the centre of the world and draws out a circle embracing the whole inhabited world (cf. Ezek 5.5). Paul regards his missionary efforts as part of the divine eschatological plan to reach the nations, those who 'have not heard of my fame or seen my glory' (Isa 66.19). The recapitulation of the 'Table of Nations' in Ezekiel 38-9, Daniel 11 and especially in Isa 66.18-29 as well as the reception and actualisation of biblical ethnography in several later texts, especially in Jubilees 8-9 and Josephus, A.J. 1.120-47, proves to Scott that eschatological-ethnic expectations were relevant in Jewish self-understanding in the first century. Paul's apostolic mission extends to the territory of Japheth, i.e. to Asia Minor, Achaia, Macedonia and the Adriatic Sea. Spain marks the goal of Paul's Japheth mission and the boundary of his missionary map. Other early Christ-followers undertook the task to travel to the regions associated with the other sons of Noah: to the descendants of Shem in the East and the descendants of Ham in the west and south. In the outline of Acts, Scott delineates the geographical strategy of the first missionary efforts: 'Shem' was under Peter's jurisdiction (Acts 2.1-8.25), 'Ham' under Philippus'

6 Deissmann, Paul, 229. On Deissmann's own debatable hypothesis, see below.

7 J. M. Scott, Paul and the Nations: The Old Testament and Jewish Background of Paul's Mission to the Nations with Special Reference to the Destination of Galatians (WUNT 84; Tübingen: Mohr Siebeck, 1995); idem, 'Luke's Geographical Horizon', The Book of Acts in its First Century Setting, vol. II: The Book of Acts in its Graeco-Roman Setting (ed. D. W. J. Gill and C. Gempf; Grand Rapids: Eerdmans, 1994) 483-544. On the 'Table of Nations' and related early Jewish geographical traditions, cf. P. S. Alexander, 'Early Jewish Geography', ABD 2 (1992) 977-88. 
(Acts 8.26-40) and 'Japheth' under Paul's (Acts 9.1-28.31). ${ }^{8}$ In a footnote Scott however entertains the idea that the regions of Ham were under the jurisdiction of Apollos of Alexandria. ${ }^{9}$

In Rainer Riesner's interpretation, Isa 66.18-21 takes centre stage. According to Riesner, 'Paul read this text as being fulfilled in his own activity, and traces of this exegesis stand behind Rom. 15:16-24. ${ }^{10}$ He concludes: 'What picture of the spread of the eschatological Gentile mission could emerge for Paul from Isa. 66:18-21? The movement obviously takes Jerusalem as its point of departure, to which God comes for the gathering of the nations (Isa. 66:18) ... This movement, beginning from Jerusalem and proceeding in a northwesterly arc to the most extreme west, would correspond to the conception lying behind Rom. 15:19. ${ }^{11}$ The phrase 'in a circle' (Rom 15.19) does not necessarily denote a full circle but might refer to a half circle. ${ }^{12}$ Rather briefly, Riesner addresses the possibility that Paul could have turned east or south after his visit to Jerusalem. Both directions, however, would have been excluded by the prophetic oracle in Isa 66.19. ${ }^{13}$

Scott asks the suggestive question: 'Is it coincidence ... that the parties in 1 Cor 1:12 are named in terms of three men [ $s c$. Paul, Apollos, Peter] who stem from the territories allotted to Noah's three sons, beginning in the north and proceeding counterclockwise?' ${ }^{14}$ However, it is indeed coincidence, since the issue of missionary territory and jurisdiction is not in view in 1 Cor $1.10-17$, not even on a secondary or tertiary level. The origin and identity of Apollos are strongly debated, and Peter does not represent a geographically oriented mission, but an ethnically oriented one (Gal 2.7). However, the grand scheme of Scott's and Riesner's 'Table of the Nations' readings in view of Paul's understanding of mission still deserves attention despite the notorious difficulties of evaluating the ethnographic terminology and imagery. ${ }^{15}$ The 'Table of Nations' tradition and, particularly, Isa 66.19 could provide 'a shaft of light which illuminates both the rationale

8 Scott, 'Luke's Geographical Horizon', 522-44; idem, Paul and the Nations, 135-80.

9 Scott, Paul and the Nations, 157 n. 106.

10 R. Riesner, Paul's Early Period: Chronology, Mission Strategy, Theology (Grand Rapids: Eerdmans, 1998) 246.

11 Riesner, Paul's Early Period, 253.

12 Riesner, Paul's Early Period, 242.

13 Riesner, Paul's Early Period, 264. He goes on (ibid.): 'By way of Alexandria, Paul could have gone to the southwest toward Libya ... or Carthage ... If he was already following his principle of working wherever possible in areas that had not already been subject to missionary activity, that probably militated against this potential destination.'

14 Scott, Paul and the Nations, 157 n. 106.

15 On the idea that the 'Roman world' (rather than Jerusalem!) is the geographical centre for Paul and his world-view, see the study by K. Magda, Paul's Territoriality and Mission Strategy: Searching for the Geographical Awareness Paradigm behind Romans (WUNT II/266; Tübingen: Mohr Siebeck, 2009). One would expect that Alexandria would play a role in a 
of Paul's mission and the compulsion he experienced to reach Spain. ${ }^{16}$ At the same time, the oracle could have played a role in eclipsing Alexandria from Paul's missionary map. It appears, however, that Paul came to read Isa 66.1821 (and Genesis 10) as a programmatic, eschatological framework for his mission only in a retrospective rationalising and theologising about his path. ${ }^{17}$

\subsection{Alexandria Was Part of the 'House of Slavery'}

In their groundbreaking work Paul between Damascus and Antioch, Martin Hengel and Anna Maria Schwemer underscore the 'Table of Nations' interpretation of early Christian mission. They conclude: 'Basically, for the first twenty years of earliest Christian history the biblical motto was: Shem, then cautiously Japhet, but not Ham. ${ }^{18}$ Hence, Egypt was not in view. The only 'scanty exceptions' to the striking silence of the New Testament texts are the Ethiopian eunuch and Apollos. Hengel and Schwemer hasten to add that the Ethiopian came into contact with the new faith not in Egypt, but on the road to Gaza, and Apollos possibly in Judea, as he allegedly only knew the baptism of John (Acts 18.25). Their inference from this gap in the sources is sweeping: 'This silence is probably an indication that the gospel came to Alexandria later than to Antioch and Rome. ${ }^{19}$ The reason for the late arrival of the gospel is neither accidental nor strategic, but purely theological and scriptural: '[W]hile already in the Old Testament period Egypt is the typical land of the exile and the Diaspora, on the other hand a return to Egypt, to the "house of slavery", was taboo, indeed was sometimes explicitly forbidden. ${ }^{20}$ Furthermore, Mizraim-Egypt is the son of Ham, who was cursed

study on Paul's Roman missionary strategy, but the Egyptian metropolis is sidelined in the book.

16 J. D. G. Dunn, Christianity in the Making, vol. II: Beginning from Jerusalem (Grand Rapids: Eerdmans, 2009) 544.

17 Cf. K.-W. Niebuhr's comments in his review of Riesner's study ( $T L Z 121$ (1996) 274-8). After all, the most evident traces of Isa 66.18-21 in Paul appear in his (late!) letter to the Romans, e.g. his priestly understanding of his apostolic ministry (Rom 15.15-16) and the signs of his ministry (Rom 15.19; cf. 2 Cor 12.12).

18 M. Hengel and A. M. Schwemer, Paul Between Damascus and Antioch: The Unknown Years (London: SCM, 1997) 260. Repeated in A. M. Schwemer, 'Zum Abbruch des jüdischen Lebens in Alexandria: Der jüdische Aufstand in der Diaspora unter Trajan (115-117 n.Chr.)', Alexandria (ed. T. Georges, F. Albrecht and R. Feldmeier; COMES 1; Tübingen: Mohr Siebeck, 2013) 381-99, at 398.

19 Hengel and Schwemer, Paul between Damascus and Antioch, 259. In the later German version of their book (M. Hengel and A. M. Schwemer, Paulus zwischen Damaskus und Antiochien: Die unbekannten Jahre des Apostels (WUNT 108; Tübingen: Mohr Siebeck, 1998) 393), they argue with greater nuance and presuppose the existence of Jewish Christianity in Alexandria, which was severely decimated in 115-17 CE.

20 Hengel and Schwemer, Paul between Damascus and Antioch, 259. Cf. Exod 14.13; Deut 17.16; 28.68; Jer 42.7-22. 
by Noah, and a brother of Canaan. ${ }^{21}$ According to Hengel and Schwemer, the period after the death of Jesus until the persecution under Agrippa was not characterised by robust missionary activities. Early Christians expected the imminent coming of Christ and experienced rejection among their non-Christian contemporaries, and they were not so much concerned with expanding their missionary territory beyond Arabia and Cilicia. Therefore, as Hengel and Schwemer need to concede, '[t]he advance of Christians to Rome seems here at first to be the exception which proves the rule'. ${ }^{22}$

Apart from the fact that the common epithet of Alexandria as Alexandria ad Aegyptum expresses a certain distinction from Egypt, the rather dark picture of Egypt painted by Hengel and Schwemer requires some elucidating. ${ }^{23}$ The early Christian tradition, which has the Holy Family travel to Egypt (Matt 2.13-15), speaks against a particularly negative stance towards this region. In Acts 6.9, Alexandrians are named, without further differentiation, next to Cyrenians and those from Cilicia and Asia as forming synagogue communities in Jerusalem. Early Christian mission did not assess the worthiness of a particular region or people prior to engaging in missionary work, and the existence of early Christian prophets who influenced Paul's and others' mission strategy is hardly demonstrable. At the end of the day, Jews constituted a remarkable community in the so-called 'House of Slavery', and were in regular contact with Jerusalem, benefiting from the comfortable travel conditions. It is plausible, however, that Paul's conviction regarding his particular missionary agenda grew stronger in the course of his ministry as he travelled 'as far around as Illyricum' (Rom 15.19). This does not preclude, but rather invites, the idea of a non-Pauline mission in Egypt and Alexandria.

\section{Cultural and Political Reasons}

\subsection{Alexandria Was Not Receptive to Another 'Universalistic' Religion}

While Hengel and Schwemer point out that Old Testament verdicts and alleged early Christian prophetic warnings resulted in a general reluctance to proceed to Egypt, others regard the religious and ideological atmosphere of Alexandrian Judaism as a strong disincentive for missionary activity. In his famed book Les apôtres Ernest Renan held that Christianity was slow to take any hold of Egypt, indeed 'Christian missionaries appear to have systematically turned their backs upon it.' Renan names three reasons: the points of contact between the Alexandrian and the Palestinian Jews were limited, the Egyptian

21 This aspect was added later (Hengel and Schwemer, Paulus zwischen Damaskus und Antiochien, 393). Cf. Gen 9.22-5; 10.13-20; vgl. Jub. 7.10, 13-16; 9.1; T. Sim. 6.46.

22 Hengel and Schwemer, Paul between Damascus and Antioch, 260.

23 Cf. the discussion in E. J. Schnabel, Early Christian Mission (2 vols.; Downers Grove: InterVarsity, 2004) I.864. 
religion afforded no favourable foundation for Christianity, and Egyptian Judaism experienced a development along its own paths. 'Egypt had Philo and the Therapeutics; that was its Christianity which deterred it from lending an attentive ear to the other. Pagan Egypt possessed religious institutions much more definite than those of Graeco-Roman Paganism: the Egyptian religion was still in all its strength.' ${ }^{\prime 24}$ Renan's far-reaching generalisation of Egypt's religious mentality (including his underlying views on race) ${ }^{25}$ and his specific stance on the relationship between the Therapeutae and Christians cannot be addressed here. ${ }^{26}$ His bottom line is that the Jewish universalism of Philo and the ascetic lifestyle of the Therapeutae created a religious atmosphere that deterred Christian missionary efforts. More poignantly: there was a kind of 'pre-Christianity' in Alexandria, which kept 'proper Christianity' out.

In more recent scholarship the Therapeutae are no longer evoked as an impediment to early Christian and Pauline mission. It is still argued, however, that the universalism of the Jewish religion in Alexandria could have discouraged or undermined Christian mission, at least amongst 'sympathisers' of Judaism. Martina Böhm observes that missionaries might have had a hard time finding 'points of contact'. ${ }^{27}$ Gerhard Sellin takes a different angle and alleges that Paul could have thought that a mission to Alexandria would jeopardise his ideas of resurrection, as laid out in 1 Corinthians $15 .{ }^{28}$ To be sure, Sellin's hypothesis depends to a large extent on his Alexandrian-Jewish characterisation of Paul's opponents in 1 Corinthians, who are, in his view, both ideological kinfolks of Philo and precursors of Alexandrian Gnosticism. ${ }^{29}$ The theological differences between Paul and Apollos were not as great as Sellin wants them to be. ${ }^{30}$ Also, it remains unclear why Paul should not have met the challenge, for in other contexts he is not prone to avoiding conflicts.

24 E. Renan, The History of the Origins of Christianity, vol. II: The Apostles (London: Mathieson, 1890) 152-3.

25 Cf. R. D. Priest, 'Ernest Renan's Race Problem', The Historical Journal 58 (2015) 309-30.

26 As is well known, the only source on the Therapeutae is Philo's De vita contemplativa. Renan considers the text to be written not by Philo but within his school; he does not deny its historicity (cf. E. Renan, Review of Moines et Sibylles dans l'antiquité judéo-grecque by F. Delaunay, Journal des Savants (1874) 796-809, at 798-9, 807).

27 M. Böhm, Rezeption und Funktion der Vätererzählungen bei Philo von Alexandria: Zum Zusammenhang von Kontext, Hermeneutik und Exegese im frühen Judentum (BZNW 128; Berlin: de Gruyter, 2005) 408.

28 G. Sellin, Der Streit um die Auferstehung der Toten: Eine religionsgeschichtliche und exegetische Untersuchung von 1. Kor 15 (FRLANT 138; Göttingen: Vandenhoeck \& Ruprecht, 1986) 70 (with reference to 1 Cor $1.11 ; 3.1 ; 4.3-6,18$ ).

29 Cf. Sellin, Streit, 290-4.

30 Contrary to Sellin, W. Schrage (Der erste Brief an die Korinther (EKKNT vII/ ; Zürich: Benziger/ Neukirchen-Vluyn: Neukirchener, 1991) 144) minimises these differences. 
Notwithstanding the difficulties of using labels such as '(Jewish) universalism', it is important to recognise that Philo indeed championed a unique convergence of 'universalist' and 'particularist' traits and developed a 'view of a comprehensive universalism which integrates Jewish traditions', in both his theology and practice. ${ }^{31}$ Whether the Philonic openness towards the surrounding culture in turn resulted in closed doors for other 'universalist' religious movements such as Christianity cannot be answered with any degree of confidence. After all, one should acknowledge that 'Philo's milieu in Jewish Alexandria' was not the only intellectual current. ${ }^{32}$ The religious soil of Alexandria also yielded 'particularistic' literary fruits such as 3 Maccabees and the Letter of Aristeas. ${ }^{33}$ In addition, a 'universalistic' outlook is, without doubt, an essential trait of Pauline Christianity, but the manner in which Philo and Paul shaped their ideas of 'universalism' leaves much room for productive competition.

In a stimulating small monograph with the programmatic title Christentum als Intellektuellen-Religion Alfons Fürst suggests that earliest Christianity took root in Alexandria as a gentile-Christian intellectual phenomenon after the end of Alexandrian Judaism. According to Fürst, Origen is the most prominent example of Alexandrian 'educated Christianity' (Bildungschristentum), and others could be placed by his side: among the 'heterodox' early Christian intellectuals we find Basilides and Isidore, Carpocrates, Epiphanes, Apelles, Valentinus and Heracleon, and among the 'orthodox' he refers to those associated to the catechetical school, Pantaenus, Clement, Heraclas, Origen and Ambrose. ${ }^{34}$ Fürst concludes: 'Christianity in Alexandria started on a high, the highest intellectual level - as a religion of intellectuals. ${ }^{35}$ Wistfully, Fürst writes that only after the demise of the type of Christian intellectual and individual did a church organisation arise, which was also common in other regions. ${ }^{36}$ Fürst is certainly correct that Alexandria became a formative force in the Christian movement only in

31 J. Leonhardt-Balzer, 'Jewish Worship and Universal Identity in Philo of Alexandria', Jewish Identity in the Greco-Roman World (ed. J. Frey, D. R. Schwartz and S. Gripentrog; AJEC 71; Leiden: Brill, 2007) 29-54, at 35.

32 E. Hilgert, 'Central Issues in Contemporary Philo Studies', BR 23 (1978) 15-25, at 22.

33 Cf. M. Simkovich, The Making of Jewish Universalism: From Exile to Alexandria (Lanham, MD: Lexington Books, 2017) 49 n. 6.

34 Fürst, Christentum als Intellektuellen-Religion, 20-33, 36-69.

35 Fürst, Christentum als Intellektuellen-Religion, 110 (my translation).

36 Fürst, Christentum als Intellektuellen-Religion, 110. In his Vienna dissertation Spuren des frühen ägyptischen Christentums, Markus Lang proposes two distinct formations of Christianity: first, a hardly tangible Jewish Christianity, then - in the wake of the Kitos War (115-17 CE) - a gentile Christianity characterised by an eclectic reception of current popular philosophy with Christian theologoumena and a subsequent gnosticising transformation. This type of Christianity Lang labels intellectual and even philosophical. Largely, this conforms to Fürst's analysis, though Lang is keen to emphasise the plurality of Alexandrian Christianity (ibid., 320 n. 2323). In contrast to Fürst (Christentum als Intellektuellen-Religion, 24, 29-33), 
the second century when Christian-'gnostic' thinkers placed and developed Christian ideas within the framework of higher education and contemporary philosophy of religion and would later themselves enrich the philosophical discourse. The labelling of this type of Christianity as 'religion of intellectuals' has been criticised, ${ }^{37}$ and even more doubtful is Fürst's reductionist argument that the lack of earlier sources proves the non-existence of Christ groups in Alexandria. Fürst does not consider if the intellectual atmosphere of Alexandria prevented an earlier arrival of the Jesus movement in Alexandria - if that would even have prevented Paul from including Alexandria into his travel plans. In fairness, Fürst's goal was to analyse the character of earliest documented Christianity in Alexandria, not to assess the reasons for its late rise. His stated method is to explicitly dismiss inferences from comparative analysis, and he pleads for an uncompromising focus on the existing sources, which are silent on the first century. This necessarily limits his proposals on the question at hand.

\subsection{Alexandria Was Politically Too Unstable during the Jewish Riots}

The ever-quotable Deissmann found the most poignant words to depict the differences between Philo and Paul: notwithstanding their many points of similarity, 'there is a very sharp contrast between them ... Philo was a writer, Paul a speaker (even his letters were spoken); ... Philo was a philosopher, Paul the fool poured out the vials of his irony upon the wisdom of the world. ... Philo is a pharos, Paul a volcano. Philo is a student and theologian, Paul a prophet and herald. Philo worked at his desk for the great literary public, Paul hurried from the workshop to the market-place and the synagogue, to see his hearers face to face. ${ }^{38}$ Even if not all of Deissmann's binary oppositions are equally persuasive, his point is well taken. He would never reach Renan's conclusion that, since Alexandria had Philo, there was no niche for Paul's mission, or any Christian mission. Deissmann, however, concedes that he cannot offer an indisputable explanation why Paul, 'who on one occasion was taken for an Egyptian' (Acts 21.38), never went to Egypt. ${ }^{39}$ He contemplates various hypotheses and finally settles on the political turmoil in Alexandria. The persecutions, which

Lang does not consider Heracleon, Carpocrates and Epiphanes to represent Alexandrian Christianity. I am grateful to Dr Lang for allowing me to consult his dissertation.

37 Cf. D. Wyrwa, 'Philosophie in der alexandrinischen Schule', PHILOSOPHIA in der Konkurrenz von Schulen, Wissenschaften und Religionen: Zur Pluralisierung des Philosophiebegriffs in Kaiserzeit und Spätantike (ed. C. Riedweg; Philosophie der Antike 34; Berlin: de Gruyter, 2017) 193-216, at 194; S. Vollenweider, 'Bildungsfreunde oder Bildungsverächter? Überlegungen zum Stellenwert der Bildung im frühen Christentum', Was ist Bildung in der Vormoderne? (ed. P. Gemeinhardt; SERAPHIM 4; Tübingen: Mohr Siebeck, 2020) 283-304.

38 Deissmann, Paul, 108-9.

39 Deissmann, Paul, 229. 
broke out 'when Paul's missionary work was beginning, made a mission to Egypt an actual impossibility and drove Paul to the North and West, even if he had intended to do missionary work in the South. Later on, when Egypt was again quiet, no doubt other persons evangelised there. ${ }^{40}$

Deissmann first expressed this idea in 1911. It transformed, he later writes, from mere assumption to certainty when H. Idris Bell published P.Lond. vi.1912 (= CPJ II.153), better known as the Letter of Claudius to the Alexandrians, in $1924 .{ }^{41}$ In this letter, dating from the autumn of $41 \mathrm{CE}$ (terminus post quem is November 10), Claudius deals among other things with the tensions between Jews/Judeans and other groups in the city. The text, which provoked a flood of secondary literature, need not be reproduced in full here. Deissmann builds his argument upon the stern warning to Alexandrian Jews, not 'to bring in or invite

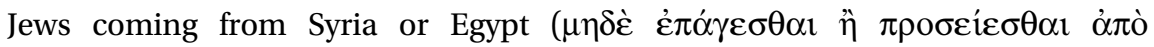

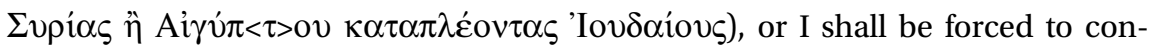
ceive graver suspicions. If they disobey, I shall proceed against them in every

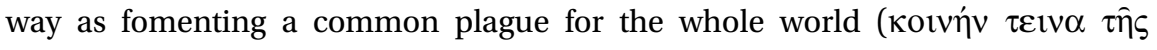

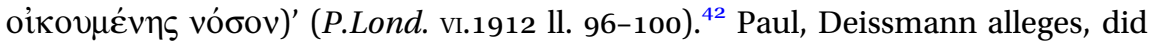
not have an 'open door' in Alexandria (cf. 1 Cor 16.9; 2 Cor 2.12).

It is quite plausible that Paul and the people surrounding him were aware of the political situation in Alexandria, and it may even be the case that political circumstances influenced his missionary agenda. However, the edict is not concerned with travel from Judea/Syria to Alexandria, but obviously guards 'against the inundation with Judean immigrants', as this would further destabilise the fragile equilibrium within the city and increase the threat of violent turmoil. ${ }^{43}$

40 Deissmann, Paul, 230-1.

41 H. Idris Bell, Jews and Christians in Egypt: The Jewish Troubles in Alexandria and the Athanasian Controversy (Oxford: Oxford University Press, 1924) 11, 14-15. Cf. Deissmann, Paul, 230-1 n. 8. See e.g. the reproduction in J. Mélèze Modrzejewski, The Jews of Egypt from Rameses II to Emperor Hadrian (trans. R. Cornman; Princeton: Princeton University Press, 1997) 181.

42 Translation from L. H. Feldman and R. Meyer, Jewish Life and Thought among Greeks and Romans: Primary Readings (Minneapolis: Fortress, 1996) 91-2 (no. 4.19).

43 B. Ritter, Judeans in the Greek Cities of the Roman Empire: Rights, Citizenship and Civil Discord (JSJSup 170; Leiden: Brill, 2015) 146. Overall, Claudius' comments are remarkably balanced, and his requests not surprising. Discussion of the edict is still going on (see the summary and relevant literature in Ritter, ibid., 7-11), and its relationship to the Claudius edict as preserved in Josephus (A.J. 19.280-5) continues to be debated. Ritter (ibid., 142-56), for instance, argues for the authenticity of Claudius' edict documented in Josephus and its predating the letter (P.Lond. VI.1912), while Andrew Harker (Loyalty and Dissidence in Roman Egypt: The Case of the Acta Alexandrinorum (Cambridge: Cambridge University Press, 2008) 25-7) suggests that P.Lond. VI.1912 and the Josephus text are both adaptations of Claudius' original edict, amended with biases towards Alexandrian Greeks and the Jews respectively. 
Furthermore, as Deissmann places Paul's decision not to go to Egypt at the beginning of his missionary work, he must presuppose a late conversion date. ${ }^{44}$

\subsection{Alexandria Was Being Closed for Christian Mission by Claudius}

In the context of the puzzling Letter of Claudius to the Alexandrians, reference needs to be made of the rather bold thesis first suggested by the French religious historian Salomon Reinach. In a paper published shortly after the editio princeps of P.Lond. VI.1912, he argued that the papyrus represented the first allusion to Christianity in (secular) history. ${ }^{45}$ In summary, he suggested that the Alexandrian outburst was 'intelligible only if Claudius had heard from his Jewish friends in Rome, especially from King Agrippa, that the Messianic agitation, both anti-Roman and anti-social, was brooding mischief in the East and even in Rome. A few years later, as the agitation continued and gained ground, Claudius banished from Rome not all the Jews, but those who took part in the disturbance' (cf. Suetonius, Claud. 25.4). ${ }^{46}$ Reinach even found an allusion to Claudius' letter in Acts 24.5, where Tertullus accuses Paul: 'We have, in fact, found this man a pestilence ( $\lambda$ ou $\mu$ óv), an agitator among all the Jews throughout the world. ${ }^{47}$ As Paul's trial in Caesarea took place in the late fifties, Reinach assumes that the letter 'must have been widely circulated and served as a warning to the Messianic Jews' ${ }^{48}$ Reinach does not relate his findings to Paul's missionary strategy, so it remains unclear whether or not he would support Deissmann's conjecture that the letter prevented Paul from aiming at Alexandria. Despite the exceedingly speculative character of his theory and the far-fetched conceptual coincidence between the letter and Acts - both refer to plague or pestilence ${ }^{49}$ - there were a number of scholars who agreed

44 Cf. Riesner, Paul's Early Period, 265. Riesner himself (loc. cit., 73-4) holds probable an early date, $31 / 2$ CE.

45 S. Reinach, 'La première allusion au christianisme dans l'histoire: sur un passage énigmatique d'une lettre de Claude', RHR 90 (1924) 108-22.

46 S. Reinach, Orpheus: A General History of Religions (rev. edn; trans. F. Simmonds; London: Owen, 1930) 244.

47 The relationship between Claudius' letter and Acts 24.5 was also highlighted by F. Cumont, 'La lettre de Claude aux Alexandrins', RHR 91 (1925) 3-6.

48 Reinach, Orpheus, 244. In the preface to this English edition he calls specific attention to this papyrus as one of two 'great discoveries', next to the Slavonic version of the Testimonium Flavianum.

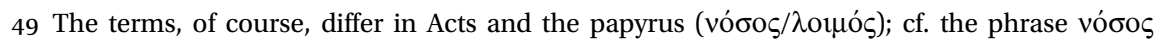
$\pi$ ó $\lambda \varepsilon \omega \varsigma$ in Plato, Prot. 322d, which shows that it was used elsewhere to describe political turmoil. See also R. Brock, Greek Political Imagery from Homer to Aristotle (London: Bloomsbury, 2013) 77 n. 7: 'For the increasingly commonplace character of the image, note the evidence of the lexicographers: Hesychius has the gloss "sick: in a state of civil war," and Pollux 8.152 [cf. 8.153] gives "to be sick: used of states of disorder and disturbance".' 
or considered it a possibility, ${ }^{50}$ but nowadays it is mostly disregarded - and rightly so. ${ }^{51}$

Claudius refers to conflicts involving Jews and Greeks, not conflicts between Jews and Jewish Jesus-followers, as was the case in Rome in 49 CE. Also, Claudius' warnings not only concern Jews sailing in from Syria, but also those sailing down the Nile to Alexandria from other regions in Egypt ('coming from Syria or Egypt'). ${ }^{52}$ Idris Bell, who published the papyrus, severely criticised Reinach's idea twenty years later: 'whatever may be thought of this, I can see no justification whatever for finding in the letter of Claudius any allusion, direct or indirect, to Christianity at Alexandria. Claudius speaks of the Jews introducing into the city their fellow-countrymen from Syria and Egypt. ${ }^{53}$ If the political circumstances were not decisive in Paul's decision to avoid Alexandria, one final set of responses to our initial question requires attention.

\section{Mission-Strategical Reasons}

\subsection{Alexandria Had Already Been Evangelized by Anonymous Jewish Christians}

One corollary of Reinach's hypothesis reflects an opinion that has nowadays established itself as the majority view. In his conclusion, Reinach wrote in the exuberant language of his time: 'l'activité, la fièvre d'idées qui se produisait dans cette jeune Eglise dut être quelque chose d'extraordinaire'. ${ }^{54}$ Even if Claudius' letter is not reflective of the dynamics of early Christianity, there are good reasons to assume that the Jesus movement was thriving and expanding and that Christianity had arrived in Alexandria at an early date. Most would

50 S. G. F. Brandon, The Fall of Jerusalem and the Christian Church (London: SPCK, 1951) 222-3; H. J. Cadbury, The Book of Acts in History (London: A \& C Black, 1955) 116-17; R. W. Smith, The Art of Rhetoric in Alexandria: Its Theory and Practice in the Ancient World (The Hague: Martinus Nijhoff, 1974) 79; G. Lüdemann, Paulus, der Heidenapostel, vol. I: Studien zur Chronologie (FRLANT 123; Göttingen: Vandenhoeck \& Ruprecht, 1980) 191. Cf. even Mélèze Modrzejewski, The Jews of Egypt, 229.

51 Cf. e.g. Schnabel, Early Christian Mission, I.857-8; Fürst, Christentum als IntellektuellenReligion, 72-4.

52 Cf. the cautious remarks in F. F. Bruce, 'Christianity under Claudius', BJRL 44 (1962) 309-26, at 312. See also J. Carleton Paget, 'Messianism and Resistance among Jews and Christians in Egypt', Jews, Christians and Jewish Christians in Antiquity (WUNT 251; Tübingen: Mohr Siebeck, 2010) 103-22, at 113. Carleton Paget (ibid., 113 n. 69) contends that it is easy to imagine 'that the arrival of Christian missionaries in the city would have caused a disturbance, particularly at the frenzied time at which Claudius wrote his letter, just as they were to do in Antioch and Rome, for example. But verisimilitude is one thing, proof another.'

53 H. I. Bell, 'Evidences of Christianity in Egypt during the Roman Period', HTR 37 (1944) 185208, at 190 .

54 Reinach, 'La première allusion au christianisme', 122. 
argue, in contrast to the above-quoted contention by Hengel and Schwemer, that the missionary impulse of early Christianity was strong from its very beginning and that the arrival of the Jesus movement in Rome in the early 40 s was not necessarily an exception. ${ }^{55}$ As it is impossible to determine a specific date for the arrival of Christianity, scholarship settles roughly on the middle of the first century. Helmut Koester wrote: 'it is indeed unthinkable that the Christian mission should have bypassed Alexandria for decades. One or several communities must have existed there as early as the second half of the 1st century. ${ }^{56}$ Possibly, the first Christ-believing Jews have entered Alexandria as early as the thirties of the first century. ${ }^{57}$ The strong religious association and the excellent travel conditions between the Jewish 'Metropolis' and the Hellenistic-Roman Metropolis are well known ${ }^{58}$ and prompt a comparison with the early journey of the Jesus movement to Rome. It is hard to prove, though not impossible, that Paul was aware of an organised early mission to Alexandria at the beginning of his own missionary endeavours and that this would have precluded his own engagement in Alexandria. As he considered himself a pioneer missionary who would not interfere with other missionaries' efforts, he did not go to Alexandria in order not to 'build on someone else's foundation' (Rom 15.20-1).$^{59}$ Another possible and even likely scenario is that the new faith was not transported by 'professional' missionaries to Alexandria, but by anonymous merchants and craftspeople and through the vibrant connection between the Jerusalem and the Egyptian diaspora, to which the Pentecost report in Acts bears witness (Acts $2.10 ; 6.9) .^{60}$

55 See e.g. Schnabel, Early Christian Mission, I.9, who remarks that ' [t] $]$ he drive to expansion is not an intrinsic, necessary element of the nature of a community of faith', but that the Jesus movement shortly after the Easter events 'actively and energetically publicized their faith in Jesus Christ'.

56 H. Koester, 'Egypt', Introduction to the New Testament, vol. II: History and Literature of Early Christianity (Berlin: de Gruyter, 2000²) 225-30, at 227. Many more voices could be added, e.g. Harnack, Mission and Expansion, II.159 n. 1; Bell, 'Evidences of Christianity', 190; Mimouni, 'Communauté chrétienne d'Alexandrie', 148; M. Clauss, Alexandria: Schicksale einer antiken Weltstadt (Stuttgart: Klett-Cotta, 2003) 202; Choat, 'Egypt's Role in the Rise of Christianity', 449.

57 Cf. Carleton Paget, 'Messianism and Resistance', 119.

58 Cf. Isa 1.26 LXX; Philo, Flacc. 46 (Jerusalem as $\mu \eta \tau \rho o ́ \pi 0 \lambda 1 \varsigma)$. See C. Hezser, Jewish Travel in Antiquity (TSAJ 144; Tübingen: Mohr Siebeck, 2011) 122, 200, on the journey of the translators of the Septuagint (Let. Aris. 301) and on the practicalities of traveling.

59 Cf. e.g. N. Hinske, Alexandrien: Kulturbegegnungen dreier Jahrtausende im Schmelztiegel einer mediterranen Grossstadt (Mainz: von Zabern, 1981) 53.

60 On this, cf. Schwemer, 'Abbruch', 398. The early arrival of Christianity in Rome has been explained along similar lines. Cf. R. Jewett, Romans (Hermeneia; Minneapolis: Fortress, 2007) 60, who also - with reserve - points to the Pentecost report in Acts and appeals to Peter Lampe's contention that Christianity took the 'trade route' to Rome (cf. Acts 28.13-14: 
The only tangible trace of an early Jewish-Christian mission is the enigmatic figure of Apollos, who is reported to have taught in Ephesus (Acts 18.24-8) and in Corinth (Acts 19.1-7; 1 Cor 1-4). Reconstructing and assessing the disparate information from Luke and Paul is notoriously difficult. ${ }^{61}$ In particular, this is true of Apollos' Alexandrian setting. In the textual tradition, there is a hint of Jewish-Christian activity in Alexandria: the varia lectio of Acts 18.25 (Codex Bezae), which is certainly secondary but might go back to the second century, reports that Apollos 'had been instructed in the word in his native city ( $\dot{\varepsilon} \vee \tau \hat{n}$ $\left.\pi \alpha \tau \operatorname{li}^{\prime} \delta\right)^{\prime}$ '. The Western text establishes what Luke's version left open: that Apollos joined a Christian community in Alexandria and can thus be called the first Egyptian Christian known by name. The 'Egyptian conversion' of Apollos is by no means certain, as any educated, presumably wealthy, Alexandrian could have become acquainted with Christianity in his travels, as already Renan suggested, ${ }^{62}$ possibly even in Judea. ${ }^{63}$ Up to today, however, these references to Apollos are taken as pivotal evidence 'to a date in the first half of the first century for the presence of a Christian community in Alexandria'. ${ }^{64}$

\subsection{Alexandria Was Evangelized by Barnabas and/or Mark after the Jerusalem Council}

Upon the successful completion of their first journey, Paul and Barnabas could have turned to other regions in the Mediterranean. ${ }^{65}$ In the winter months after their return, they - together with the collegial leadership in Antioch - probably forged plans for further action, and after the 'Apostolic Council' (probably in $48 \mathrm{CE}$ ), ${ }^{66}$ the plans needed to be substantiated, fleshed out and executed. Possibly, they had to choose between revisiting the Christ groups

port of Puteoli) and that 'Jewish slaves and freedmen/women attached to Roman households brought Christianity to Rome' (cf. 1 Clem 63.3; 65.1).

61 See the recent attempts by C. Clivaz, 'Reading Luke-Acts in Second Century Alexandria: From Clement to the Shadow of Apollos', Engaging Early Christian History: Reading Acts in the Second Century (ed. R. R. Dupertuis and T. Penner; Durham: Acumen Publishing, 2013) 209-23; J. Wehnert, 'Apollos', Alexandria (ed. T. Georges, F. Albrecht and R. Feldmeier; COMES 1; Tübingen: Mohr Siebeck, 2013) 403-12; S. Vollenweider, 'Apollos of Alexandria: Portrait of an Unknown', Alexandria: Hub of the Hellenistic World, 325-44.

62 Renan, The Apostles, 152.

63 Cf. Hengel and Schwemer, Paul between Damascus and Antioch, 259.

64 R. E. Heine, Origen: Scholarship in the Service of the Church (Oxford: Oxford University Press, 2010) 27; A. F. J. Klijn, 'Jewish Christianity in Egypt', The Roots of Egyptian Christianity (ed. B. A. Pearson and J. E. Goehring; Minneapolis: Fortress, 1986) 161-7, at 163-4. See, however, the more cautious approach in Vollenweider, 'Apollos of Alexandria'.

65 On what follows, see M. Öhler, Barnabas: Die historische Person und ihre Rezeption in der Apostelgeschichte (WUNT 156; Tübingen: Mohr Siebeck, 2003) 451.

66 On the issues of dating, cf. Riesner, Paul's Early Period, 319-21. 
they had founded during their first journey, yet another visit to the regions in which the first mission was less successful (e.g. Cyprus), and the expansion of the mission to other areas in Asia Minor, Greece and even beyond. Possibly, Alexandria figured in these plans, but even if this were the case, the idea was dropped. Luke has Paul say to Barnabas that they would set out from Antioch to revisit the communities they founded during their first trip (Acts 15.36).

Even if this decision is quite understandable, our initial question can be asked even at this stage in Paul's career since his travel plans were not carved in stone (cf. Acts 16.6, 7) and he was always eager to break new ground. Why did he ignore Alexandria at this point? Luke mentions a controversial exchange between Paul and Barnabas in Antioch, who wanted to add a third member to the team, John Mark (Acts 15.36-9), Barnabas' cousin (?) (cf. Col 4.10). The dispute ended in a division, because Paul was resentful towards John Mark for leaving them in Pamphylia, but the division in turn likely 'resulted in an expansion ... of the mission'. ${ }^{67}$ In fact, Luke reports that Barnabas and John Mark continued their mission work in Cyprus, Barnabas' home country (Acts 4.36; 15.39), while Paul thought on a large scale and wanted eventually to set foot in 'Europe'. It has been asked whether or not the information about the travel of Barnabas and John Mark to Cyprus is reliable, since the existence of Christian communities in Cyprus remains obscure, ${ }^{68}$ but for our purposes we have to turn to an even more controversial question: did Barnabas and Mark think on a large scale as well, and set out to visit Alexandria? Did the controversy between Paul and Barnabas concern not only the missionary team, but also the missionary strategy, with Paul turning to the 'west' and Barnabas, together with John Mark, to the 'south'? ${ }^{69}$

After the incident between Paul and Barnabas, all trace of the latter is lost in Acts. Not so in Paul's letters: Paul himself indicates that Barnabas is still active as a missionary in the mid fifties (1 Cor 9.6). One would assume that he did not stay in Cyprus throughout these years, and a trip from Cyprus to Alexandria would certainly not be seen as odd. ${ }^{70}$ Several other arguments have been put forward for Barnabas' travel to Alexandria, based on a presumably old tradition reported in the Pseudo-Clementine Homilies (1.9.1-2) that 'a Hebrew man

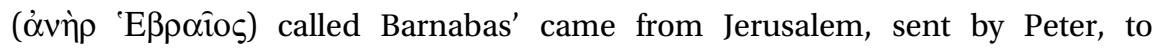
preach the gospel in Alexandria. There is a worthwhile minority opinion that is

67 R. I. Pervo, Acts (Hermeneia; Minneapolis: Fortress, 2009) 386.

68 Cf. Öhler, Barnabas, 450. But see Harnack, Mission and Expansion, II.140: 'Jews abounded in Cyprus, so that the way lay open for the Christian propaganda.'

69 On this complex of questions, see the optimistic, but thought-provoking study by J. J. Gunther, 'The Association of Mark and Barnabas with Egyptian Christianity (Part I)', EvQ 54 (1982) 21932; idem, 'The Association of Mark and Barnabas with Egyptian Christianity (Continued)', EvQ 55 (1983) 21-9.

70 Cf. T. Zahn, Skizzen aus dem Leben der alten Kirche (Leipzig: Deichert, 1908 $\left.{ }^{3}\right) 343$ n. 32. 
willing to give some credence to an Alexandrian visit by Barnabas. Gilles Quispel deems this 'an extremely trustworthy tradition, because it contradicts the official version, according to which Mark, the author of the Gospel, had come from Rome to found the Church there'. ${ }^{71}$ Obviously, the question of Barnabas' visit to Alexandria is related to the question of the provenance of the Epistle of Barnabas, which is equally contested. For many scholars, Alexandria remains the most convincing solution, particularly due to its relationship to texts and traditions of Alexandrian origin. There, the continuity with Jewish messianism and other millennial hopes, the anti-Roman bias and the figurative modes of interpretation can be situated in a setting where 'Jewish literal interpretation of the law is harshly condemned and Jewish nationalistic promises are interpreted in a broadly Christocentric manner'. ${ }^{72}$ In particular, the figurative hermeneutics has obvious equivalents among Alexandrian exegetes, both Jewish (e.g., Philo) and Christian (e.g., Origen).$^{73}$ Apart from that, Clement of Alexandria is the first to quote from the Epistle of Barnabas, and the Codex Sinaiticus, an 'Alexandrian' version of the New Testament text, includes it. Citing Quispel's thesis, James Carleton Paget writes: 'If Barnabas did in fact visit Egypt, then the ascription of a letter to him written in Alexandria would make sense. ${ }^{74}$

An even better attested tradition links John Mark with the foundation of the Alexandrian church (e.g. Eusebius, $H E$ 2.16) - 'they say' ( $\varphi \alpha \sigma i v)$ that Mark spread the gospel in Egypt and founded 'churches first of all at Alexandria

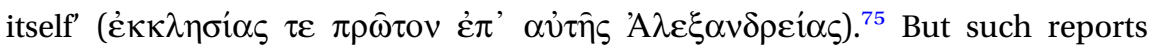
bear clear signs of a later founding legend ${ }^{76}$ and presuppose an impossible

71 G. Quispel, Review of Early Egyptian Christianity from its Origins to $451 C E$ by C. W. Griggs, VC 45 (1991) 205-6, at 206. Mimouni, 'Communauté chrétienne d'Alexandrie', 154: 'On doit cependant se demander si Barnabé, mandaté par les Hébreux de Jérusalem ou les Hellénistes d'Antioche, n'a pas joué un rôle important dans la première mission chrétienne d'Alexandrie.'

72 Carleton Paget, 'Messianism and Resistance', 119. Cf. ibid., 113-15 and extensively idem, The Epistle of Barnabas: Outlook and Background (WUNT ıI/82; Tübingen: Mohr Siebeck, 1994) 30-42.

73 Cf. the summary in B. Ehrman, 'Introduction to The Apostolic Fathers' (LCL 24; Cambridge: HUP, 2003), 7-8.

74 Carleton Paget, The Epistle of Barnabas, 36.

75 Cf. Harnack, Mission and Expansion, II.162. See the summary of the evidence in Mimouni, 'Communauté chrétienne d'Alexandrie', 154-7; also L. W. Barnard, 'St. Mark and Alexandria', HTR 57 (1964) 145-50.

76 A. Jakab (Ecclesia Alexandrina, 110-15) attributes Eusebius's note to the first of three stages in the development of the Alexandrian tradition about Mark. Making Mark the founding figure of the Alexandrian church connects bishop Demetrius ( $c a$ 189-232) to the bishop of Rome by the agency of Peter and Mark. In this context, we should recall Hans Lietzmann's suggestion (Geschichte der alten Kirche (Berlin: de Gruyter, 1975/5) 379-80) that Mark's relationship with Alexandria reflects the historical truth that the Alexandrian church was founded by Rome as a kind of subsidiary church (on the implausibility of this view, already C. H. 
chronology. ${ }^{77}$ Historically, only his alliance with Barnabas (Acts 15.39; cf. again Eusebius, $H E$ 2.16) might point to a possible visit by Mark to Alexandria.

With reference to Rom 15.18-20 and against the backdrop of an optimistic reading of the Barnabas tradition, John Gunther suggested that in the later stage of his mission Paul excluded Alexandria from his territory, because 'he did not wish to trespass in the domain of Barnabas, the other apostle to the Gentiles. Why else did Paul not plan to stop in Alexandria and Cyrene on the way from Jerusalem to Rome after delivering his gift to "the saints"? Barnabas stayed out of Paul's territory, even in Asia Minor where he had been on their "first journey". They subsequently acted as if they had made an agreement on the division of missionary territory when they personally parted ways. ${ }^{78}$ Gunther's proposal and its numerous implications need not be discussed here, but his main thesis should not be dismissed prematurely: Barnabas (and Mark) could have come to Alexandria, after Barnabas and Paul parted ways, and this would possibly have restrained Paul from considering a visit to the metropolis. Perhaps, a dissent over their mission strategy - indeed over the question about what is 'gentile territory' - might have incited conflict. In the end, subjunctive phrasing best reflects our ignorance.

\subsection{Alexandria Was Part of the Jewish-Christian Mission}

It is pure conjecture that a divergent definition of 'gentile territory' could have caused trouble between the two 'gentile missionaries' Paul and Barnabas. But it is very likely that Paul considered Alexandria 'as belonging not to Gentile countries, but to the "circumcision", and thus as Peter's mission field' (cf. Gal 2.9). ${ }^{79}$ Deissmann considered this option as a possible answer to Paul's omission of Alexandria but dropped it in favour of another, less likely, one. Deissmann had continued his thought experiment. Paul 'is jealously concerned that every missionary should have his own province and not go beyond it [2 Cor 10.13-18; Rom 15.20], and in particular he had no doubt faithfully kept to his compact with the "pillar apostles" [Gal 2.9]. ${ }^{80}$

Roberts, Manuscript, Society and Belief in Early Christian Egypt (The Schweich Lectures 1977; London: The British Academy, 1979) 59 n. 1; see also Fürst, Christentum als IntellektuellenReligion, 103.

77 In the same context (HE 2.16-17), Eusebius notes that the ascetic and philosophical ethos of the numerous converts attracted the attention of Philo, who based his treatise on the Therapeutae on this ethos, and - when in Rome on behalf of the Alexandrian Jews - even conferred with Peter.

78 Gunther, 'Association (Part I)', 229.

79 Deissmann, Paul, 230.

80 Deissmann, Paul, 230. 
Even if more than one of the explanations presented so far might contain a germ of truth, in my opinion the decisive factor for Paul's passing over Alexandria was his conviction that it belonged to the Jewish-Christian mission territory. ${ }^{81}$ If it is true, as both Paul himself and Luke credibly relate, that Paul considered himself an 'apostle of the gentiles' as a consequence of his call (cf. Gal 1.16; Acts 9.15), Alexandria was never part of his field of vision for his own missionary activity. At the latest, it had vanished after the 'Apostolic Council', which codified the distribution of the mission territories. ${ }^{82}$

In the first century, the population of Alexandria reached half a million, which made it second in size only to Rome. Other estimates even propose a population of up to 1.5 million. ${ }^{83}$ Three groups constitute the administrative structure and characterise the ethnic and socio-cultural atmosphere of Roman Alexandria in the first century CE: Greeks, Egyptians and Jews. These groups are quite selfaware of their ethnic, political and economic status, and they are quite self-confident regarding their respective legal privileges and cultural identities. The effect is both 'unique, creative diversity' and 'constant social and ethnic unrest' ${ }^{84}$

Jews have been part of the ethnic and religious landscape of Egypt since the sixth century $\mathrm{BCE}$ and inhabited Alexandria from its foundation. In fact, 'the Macedonian conquest opened the floodgates of a new Jewish immigration to Egypt' ${ }^{85}$ Josephus' statement that Alexander himself gave the Jews the right to settle in Alexandria is historically dubious. ${ }^{86}$ The Letter of Aristeas (12) in combination with the Satrap stela (dated 29 August 311), however, suggests that Jews came to Alexandria as prisoners of war after Ptolemy Lagos's campaign in Gaza

81 Cf. e.g. A. Heckel, Die Kirche von Ägypten: Ihre Anfänge, ihre Organisation und ihre Entwicklung bis zur Zeit des Nicänum (Strassbourg: Heitz, 1918) 77; M. Hornschuh, Studien zur Epistula Apostolorum (PTS 5; Berlin: de Gruyter, 1965) 115; Ritter, 'Das frühchristliche Alexandrien', 125-7; J. Mélèze Modrzejewski, 'Ägypten', Rom und das Reich in der hohen Kaiserzeit, 44 v. Chr.-26o n. Chr., vol. II: Die Regionen des Reiches (ed. C. Lepelley; Leipzig: Saur, 2001) 457-518, at 509.

82 G. Quispel ('African Christianity before Minucius Felix and Tertullian', Gnostica, Judaica, Catholica (Leiden: Brill, 2008) 387-459, at 407) holds that for this reason Paul ignored not only Alexandria, but also Carthage and Edessa. Even this is plausible.

83 The number 500,000 appears to establish itself as consensus. See D. Delia, 'The Population of Roman Alexandria', TAPA 118 (1988) 275-92, at 275 n. 2 for an overview of modern attempts to assess the population of Alexandria. For the consensus view, see e.g. J. Rowlandson and A. Harker, 'Roman Alexandria from the Perspective of the Papyri', Alexandria Real and Imagined (A. Hirst and M. Silk; Aldershot: Ashgate, 2004) 79-111, at 84.

84 J. Zangenberg, 'Fragile Vielfalt: Beobachtungen zur Sozialgeschichte Alexandrias in hellenistisch-römischer Zeit', Alexandria (ed. T. Georges, F. Albrecht and R. Feldmeier; COMES 1; Tübingen: Mohr Siebeck, 2013) 91-107, at 91.

85 Mélèze Modrzejewski, The Jews of Egypt, 73.

86 Cf. Josephus, C. Ap. 2.36-37, 42; B.J. 2.487. 
in 312-311 BсE. $^{87}$ Others came in later decades as mercenaries, merchants and craftsmen and carried with them not only their skills and goods, but also their conceptions of God and the world. The Jewish population of Alexandria was immense, though the exact number remains disputed. Josephus' and Philo's figures seem exaggerated. Philo, for instance, affirms that Egyptian Jews amounted to a million in his day, ${ }^{88}$ and Josephus counts 50,000-60,000 Alexandrian Jews killed in $66 \mathrm{CE}^{89}$ At present, the scholarly consensus levels out at $c a 150,000(+/-30,000)$ Jews at the beginning of the first century $\mathrm{CE}$, i.e. one third of the Alexandrian population was Jewish. ${ }^{90}$ The Jewish part of the population in Alexandria was a major factor in the 'fragile diversity' of the metropolis, ${ }^{91}$ and the above-quoted Letter of Claudius to the Alexandrians is but one piece of evidence for the difficulty to maintain the vulnerable equilibrium between the different groups. In line with Claudius' directives, the imperial and local rulers were eager to respect the status quo and did so, by and large successfully, even during the Jewish War from 66 to $70 \mathrm{CE}$. Yet the extreme political and cultural tensions erupted at the diaspora revolt $\left(115^{-17} \mathrm{CE}\right)$ which almost annihilated the Jewish communities in Egypt and Northern Africa.

In recent decades, scholarship has identified a number of aspects suggesting continuities between Alexandrian Judaism, earliest Jewish-Christianity and post-117 CE Alexandrian Christianity, with a growing awareness of the problematic labels 'Jewish', 'Jewish-Christian' and 'Christian' for this time period. So far, the scattered evidence has not been gathered, systematised and evaluated in a comprehensive and conclusive manner. ${ }^{92} \mathrm{I}$, too, have to leave it at some short remarks, as follows. ${ }^{93}$

87 Cf. S. Gambetti, The Alexandrian Riots of $38 \mathrm{CE}$ and the Persecution of the Jews: A Historical Reconstruction (JSJSup 135; Leiden: Brill, 2009) 23-4.

88 Philo, Flacc. 43. Harnack (Mission and Expansion, I.6), however, deems Philo's number credible due to his 'comparatively precise mode of expression' and due to the fact 'that registers for the purpose of taxation were accurately kept in Egypt'. The figure does not appear too high, 'when we consider that it includes the whole Jewish population of Alexandria. As the entire population of Egypt (under Vespasian) amounted to seven or eight millions, the Jews thus turn out to have formed a seventh or an eighth of the whole.'

89 Josephus, B.J. 2.497, 7.369.

90 Cf. Delia, 'The Population of Roman Alexandria', 286-8; Mélèze Modrzejewski, The Jews of Egypt, 73-4; D. Sly, Philo's Alexandria (New York: Routledge, 1996) 44-6; P. W. van der Horst, Philo's Flaccus: The First Pogrom. Introduction, Translation and Commentary (PACS 2; Leiden: Brill, 2003) 136-7; D. R. Schwartz, 'Philo, his Family and his Times', The Cambridge Companion to Philo (ed. A. Kamesar; Cambridge: Cambridge University Press, 2009) 9-31, at 15.

91 On this characterisation, see Zangenberg, 'Fragile Vielfalt', 106.

92 Obviously, this is a Sisyphean task that is both fraught with uncertainties and dependent on scholarly imagination. See e.g. the valuable attempts of Jakab, Ecclesia Alexandrina; Lang, Spuren des frühen ägyptischen Christentums.

93 For a fuller discussion, see Schliesser, 'Jewish Beginnings'. I am pleased to note that Tobias Nicklas arrives at compatible results in a forthcoming study: T. Nicklas, 'Jews and 
(1) Alexandrian Christianity used the Alexandrian Jewish Septuagint and collected and disseminated the writings of Philo, which counts as one of 'the most obvious signs of continuity'. ${ }^{94}$ Especially the early Christian invocations of Philo can be meaningfully understood in the context of 'ongoing efforts by Christians to conceptualize and demarcate the difference between two emerging but fluid collective identities, "Christianness" and "Jewishness"'.95

(2) A number of Christian writings that can be traced to Alexandria (with various degrees of probability) show clear marks of Jewish heritage and variegated strategies for negotiating identities in a multicultural context. It is possible to discern a Petrine strand of Alexandrian Christianity, i.e. a 'Petrine discourse' (Epistle of Barnabas, Kerygma Petri, Apocalypse of Peter, 2 Peter, Sibylline Oracles), ${ }^{96}$ but also a 'Jacobean discourse' in the widest sense (Gospel according to the Hebrews, Protevangelium Jacobi). ${ }^{97}$

(3) These writings reflect Jewish messianic and millennial hopes, apocalyptic concepts, ethical traditions etc., they connect to, or polemicise against, Jewish ideas and symbols, and they oftentimes engage in figurative modes of interpretation, which are familiar to us from Philo. Apollos remains an enigma: though both his (Philonic?) education and his (Alexandrian?) conversion will always remain in the dark, the idea that he formed his Christology against the backdrop of Alexandrian-Jewish wisdom theology remains a valid possibility. ${ }^{98}$

Christians? Sketches from Second Century Alexandria', Jews and Christians: Parting Ways in the First Two Centuries $C E$ ? (ed. J. Schröter et al.; Göttingen: Vandenhoeck \& Ruprecht). Among those who suggest a thoroughly 'Jewish' character of earliest Alexandrian Christianity are A. von Harnack, M. Hornschuh, C. H. Roberts, H. Koester, A. F. J. Klijn, B. Pearson, A. M. Ritter, C. Markschies, A. Jakab, J. Mélèze Modrzejewski, M. Hengel, A. M. Schwemer, S. Mimouni and M. Lang.

94 Pearson, 'Earliest Christianity', 100; cf. Kraft and Luijendijk, 'Christianity's Rise after Judaism's Demise', 180.

95 J. Otto, Philo of Alexandria and the Construction of Jewishness in Early Christian Writings (Oxford: Oxford University Press, 2018) 4.

96 On the concept of a 'Petrine discourse' in Alexandria, see J. Frey, 'Second Peter in New Perspective', 2 Peter and the Apocalypse of Peter: Towards a New Perspective (ed. J. Frey, M. den Dulk and J. van der Watt; BibInt 174; Leiden: Brill, 2019) 7-74.

97 Alexandrian provenance of other 'Jewish-Christian' New Testament writings (e.g. Hebrews, James, Jude) and non-canonical texts (e.g. 2 Clement, Epistula apostolorum) is less likely. Cf. the analysis in J. Frey, 'Locating New Testament Writings in Alexandria: On Method and the Aporias of Scholarship', Alexandria: Hub of the Hellenistic World, (ed. B. Schliesser, J. Rüggemeier, T. Kraus and J. Frey; WUNT; Tübingen: Mohr Siebeck, 2021) 345-65.

98 Cf. Wehnert, 'Apollos', 412. 
(4) The early reception of Jewish-Christian writings which are not of Alexandrian provenance but enjoyed great popularity there suggests an early Jewish-Christian readership (e.g. Hermas). ${ }^{99}$

(5) The treatise of Celsus ( $c$ a $180 \mathrm{CE}$ ), as reported by Origen, calls upon a 'Jew' either a literary fiction of Celsus or, more likely, a real author - who engages in polemics against the Jesus movement and who invokes the rather diplomatic Dialogue between Papiskos and Jason ( $\mathrm{ca} 120 \mathrm{CE}$ ). This probably Alexandrian text could be the first known exemplar of the JewishChristian dialogue genre, featuring a studious debate and the ensuing conversion of the Jewish interlocutor. As a literary product it condenses a broader and earlier discourse, which clearly reaches beyond the time of the revolt.

(6) Jewish-Christian elements are also evident in what came to be labelled 'Gnosticism'. Although tracking down second-century tradition in fourthcentury texts harbours severe methodological problems, the Nag Hammadi Gnostic Library could give us a hint 'that in second-century Egypt, Jewish-Christian conceptions and traditions played a part in several Gnostic speculations'. ${ }^{100}$ Furthermore, the fragments of Valentinus suggest his relationship to Hellenistic Judaism in Philonic shape. $^{101}$

(7) The unique profile of the Catechetical School in Alexandria as a Christian philosophical school could have originated as indirect outcome of structures of Jewish teaching institutions, ${ }^{102}$ and the presbyterate and the office of teachers in Alexandrian congregations as well as their counterparts in some 'gnostic schools' may reflect leadership structures of the synagogue. ${ }^{103}$

99 Cf. M. Choat and R. Yuen-Collingridge, 'The Egyptian Hermas: The Shepherd in Egypt before Constantine', Early Christian Manuscripts: Examples of Applied Method and Approach (ed. T.

J. Kraus and T. Nicklas; Leiden: Brill, 2010) 191-212; D. Batovici, 'Hermas in Clement of Alexandria', StPatr 66 (2013) 41-51.

100 R. Van den Broek, 'The Shape of Eden according to Justin the Gnostic', Studies in Gnosticism and Alexandrian Christianity (Nag Hammadi and Manichaean Studies 39; Leiden: Brill, 1996) 131-41, at 140 .

101 C. Markschies, Valentinus Gnosticus? Untersuchungen zur valentinianischen Gnosis mit einem Kommentar zu den Fragmenten Valentins (WUNT 65; Tübingen: Mohr Siebeck, 1992) 323 and 407 ('geistige Zwischenstufe zwischen Philo und Clemens Alexandrinus').

102 Wyrwa, 'Philosophie in der alexandrinischen Schule', 198. Cf. Mimouni, 'Communauté chrétienne d'Alexandrie', 161.

103 Pearson, 'Earliest Christianity', 105. Moreover, Pantaenus has been described as the mediator between a Jewish-Christian and a Hellenistic type of Christianity and even as a preserver of Philo's works (cf. D. T. Runia, 'Witness or Participant? Philo and the Neoplatonist Tradition', Philo and the Church Fathers: A Collection of Papers (Supplements to Vigiliae Christianae 32; Brill: Leiden, 1995) 182-205, at 191). 
(8) Even the Alexandrian scribes' use of nomina sacra could 'shed some illumination, however sparse, on the dark period of the Church in Egypt', in that they bear witness to early Jewish-Christian scribal habits. ${ }^{104}$

(9) Onomastic data provide certain clues on the Jewish character of earliest Christianity ${ }^{105}$ but at the same time point to the problems of a simple correlation of religious conversion and onomastic change. ${ }^{106}$ In any case, by the end of the fourth century, the proportion of Christians in Egypt was substantial (70 per cent to 90 per cent, based on onomastic data).

(10) Still more hypothetical are the growth rates of the Jesus movement, ${ }^{107}$ but it appears that the thesis of a late, 'pagan' rise of Christianity without any Jewish-Christian pre-history has to reckon with almost miraculous rates of conversion or large-scale immigration. A realistic estimate of Christbelievers at the turn of the first century is at least a hundred, most of whom were Jewish. ${ }^{108}$

(11) Finally, Paul's neglect of Alexandria adds another piece to the puzzle. Paul skipped Alexandria because he considered it to be Palestinian missionary territory and because he was, most likely, aware that the Christian faith had already taken root in this metropolis.

Taken cumulatively, the traces of Jewish elements in the texts, traditions and organisational forms of Alexandrian Christianity from the second century onwards hardly allow for any conclusion other than that the first 'rise of Christianity' in Alexandria had a thoroughly Jewish character. Once again, von Harnack's erudition and intuition prove sound, ${ }^{109}$ despite the classic challenge of this view by

104 Roberts, Manuscript, Society and Belief, 48. Cf. L. W. Hurtado, The Earliest Christian Artifacts: Manuscripts and Christian Origins (Grand Rapids: Eerdmans, 2006) 114 on the example of Abraham's 318 servants (Gen 14.14): both the Epistle of Barnabas (9.7-8) and Clement (Strom. 6.278-80) refer to the shape of the cross $(\mathrm{T}=300)$ and to the numerical value of the first two letters of IH $\Sigma$ Or $\Sigma(\mathrm{IH}=18)$.

105 R. S. Bagnall, 'Religious Conversion and Onomastic Change in Early Byzantine Egypt', BASP 19 (1982) 105-24; idem, 'Conversion and Onomastics: A Reply', ZPE 69 (1987) 243-50; M. Depauw and W. Clarysse, 'How Christian was Fourth Century Egypt? Onomastic Perspectives on Conversion', VC 67 (2013) 407-35.

106 See the dialogue between D. Frankfurter, 'Onomastic Statistics and the Christianization of Egypt: A Response to Depauw and Clarysse', VC 68 (2014) 284-9 and M. Depauw and W. Clarysse, 'Christian Onomastics: A Response to Frankfurter', VC 69 (2015) 327-9.

107 R. Stark (The Rise of Christianity: How the Obscure, Marginal Jesus Movement Became the Dominant Religious Force in the Western World in a Few Centuries (New York: Harper, 1997), 5-6) assesses the growth rate of early Christianity in the Roman Empire to approximate 40 per cent per decade.

108 See Schliesser, 'Jewish Beginnings', 392, with more details.

109 E.g. Harnack, Mission and Expansion, II.159 with n. 2: 'It is more than a conjecture, however, that a larger number of Jews were converted to Christianity in the Nile valley than anywhere else.' 
Walter Bauer and the more recent attempt by Fürst. The lack of primary evidence is certainly lamentable, but, at the same time, explainable. The tensions between the Jews and Greco-Romans in Alexandria, particularly the revolt from 115 to 117 CE but also the less violent disturbances, undoubtedly had an impact on the process of 'Christianising' Alexandria. The theory of a complete annihilation is not plausible, ${ }^{110}$ as it cannot explain the substantial continuities between Alexandrian Judaism and Alexandrian Christianity after $117 \mathrm{CE}$ 'in terms of theology, lifestyle and social organization'. ${ }^{111}$ And it cannot explain how, two generations later, the church should have become - in von Harnack's words - 'a stately church'. $^{112}$

\section{Conclusion}

If one starts from the premise that Paul was a missionary strategist with a considerable spatial imagination, ${ }^{113}$ the question 'Why did he skip Alexandria?' is by no means irrelevant or trivial. The answers to this question are partly complementary, partly contradictory. A first set of possible solutions pertains to theological and scriptural reasons and a 'salvation-historical' understanding of his mission. Did Paul decide to travel to the north and west rather than the south because he did not count the city of Alexandria among the 'Table of the Nations'? Did he even believe that Alexandria belonged to the 'House of Slavery'? A second set of deliberations takes into account the cultural and political circumstances in Alexandria. Was Paul worried that the gospel would not fall on fertile soil in the 'universalistic' religious ecosystem of Alexandria? Was he afraid of getting caught up in the turmoil between Jews and Greeks and that effective mission was impossible? Did the emperor Claudius suppress travels of Jews including Jewish-Christian missionaries! - to Alexandria? A third set of reflections points to mission-strategical reasons for the omission of Alexandria. Was Paul aware that Alexandria had already been evangelised by (anonymous) JewishChristians, and his self-understanding as a pioneer missionary kept him from interfering? Did he entrust the city to the missionary work of Barnabas (and

110 Mélèze Modrzejewski, The Jews of Egypt, 228: '[I]f primitive Christianity had not left any marks on Egyptian soil until the end of the second century, it was because it had been annihilated along with the entire body in which it was immersed - the Jewish community of Alexandria.'

111 Pearson, 'Egypt', 337. Cf. Mimouni, 'Communauté chrétienne d'Alexandrie', 161; Kraft and Luijendijk, 'Christianity's Rise after Judaism's Demise', 185.

112 Harnack, Mission and Expansion, II.158-9.

113 Cf. J. Rüggemeier, 'Die innere Landkarte des Paulus: Zur Raumkonzeption und deren Begrenzung in den paulinischen Schriften', BuK 73 (2018) 94-101. To be sure, Paul's assumed geographical imagination was not based on 'cartographic' knowledge, but on a more topographical and relational vision as evidenced in ancient itineraria. 
Mark), after they had split? Or did the Jewish character of Alexandria convince him that this part of the Mediterranean was under the jurisdiction of the Palestinian mission? The final answer has proven the most plausible one: Paul skipped Alexandria because it was a Jewish city and as such part of the JewishChristian mission. 